\section{A.O.U. MEETING IN WINNIPEG}

The 93rd annual meeting of the herican Ornithologists' Union O.U.) will be held on the University Manitoba campus from Monday to day, August 25 through 29, 1975. e A.O.U. is the oldest and largest fessional ornithological society in Western Hemisphere and it is thus eed an honour for us to be able to t its annual meeting in Winnipeg. is will be only the second time that Meeting has been held in wester $n$ hada; the first was in Regina in 59.

Experts in all aspects of ornithology $m$ all over North America and bably from several foreign counes - artists, lecturers, ptographers, researchers, conserionists - will be on hand to discuss latest discoveries and advancents in the study of birds. This is opportunity to rub elbows with ie of the foremost ornithologists of time. Yes, Roger Tory Peterson probably be here!

Ho mAY ATTEND: All ornithologists, dwatchers and naturalists are ined to register and attend this cting. One need NOT be a member the A.O.U. in order to attend. Too entific? Not so! The role of the ateur in the field of ornithology, $h$ past and present, is continually ng emphasized. All activities (ext business sessions) are open to -A.O.U. members. There will be a istration fee of $\$ 8.00$ ( $\$ 12.00$ for a ried couple) and a charge of $\$ 4.75$ the banquet.

ACE: University Centre in the Idle of the University of Manitoba ipus.

Oogramme: SUNDAY, August 24: yistration in late afternoon and ly evening. MONDAY, August 25: gistration (all day); business etings for Council Members, lows, Elective Members: all-day d trip to Delta Marsh and Delta terfowl Station (leaving 9:00 a.m.): afternoon field trip to Oak Hammock Marsh (leaving 1:30 p.m.); getacquainted hour at $8: 30$ p.m. TUESDAY, August 26: Registration (all day); papers being given all day; activities for wives of delegates; tour of the David Loch gallery of wildlife art in St. Vital; information reception in University Centre in evening. WEDNESDAY, August 27: Registration (all day); papers given all day; ornithological films at $8: 30$ p.m. THURSDAY, August 28: Papers all day; annual banquet at 7:00 p.m. FRIDAY, August 29: All-day field trip to Hecla Island (leaving at 7:30 a.m.).

Arrangements are being made for local bird trips each morning before the sessions start.

For preregistration forms and other information, please contact Dr. Spencer Sealy, Chairman, Local Committee on Arrangements, Department of Zoology, University of Manitoba, Winnipeg.

\section{III 卙品 And}

The April-May-June, 1945, Blue Jay contained $10 \quad 8-1 / 2 \quad$ X 11 mimeographed pages. Some of the items from it were:

Judge L. T. McKim of Melville recalled rare birds he had seen over the previous 20 years. He also noted that the "first pair of Arkansas Kingbirds appeared in Melville in 1924, and for four years running, nested behind a can on an electric light pole at the back of our yard ... These kingbirds are now quite common here and are reported much further north than Melville". . Dick Beddoes conducted a Christmas Bird Count on Dec. 28, 1944, at Daysland, Alberta; he remarked "that the Sharp-tailed Grouse is down in numbers and that, for the first time since he has been making Christmas Censuses, he did not see a single true Prairie Chicken"...H. H. Pittman of 
Wauchope reported that two pairs of orioles built nests and then disappeared. "Shortly after this I noticed a kingbird perched beside one of the oriole nests and found that another kingbird was actually inside the nest. There were, however, no eggs in this nest. A few days later we saw the kingbirds at the other nest and found it contained four eggs. These were hatched in due course and I was able to get a series of pictures of the Eastern Kingbird feeding its young in the nest of the Baltimore Oriole" ... R. C. Mackenzie reported on tapping Manitoba Maples along the Carrot River to collect syrup and make sugar

On hibernating frogs: "one spring Mrs. Marion Nixon disturbed an old hot bed, and huddled there at the junction of soil and manure were about twenty small Swamp Tree Frogs. The ground was still partly frozen and some of them were still encased in icy soil - but just as soon as a clod became broken to expose a leg, that leg would start wiggling, flexing rhythmically and slowly, and soon the owner would squirm his whole body free". . What happens to dead skunks? C. Fehrenbach of Saltcoats wrote that "A few years ago he shot a skunk about six feet from a small culvert. The body lay around for some days and then it too disappeared leaving only a slight depression in the grass where it had lain. But near the opening of the culvert Mr. Fehrenbach noticed that the soil had been disturbed as if some animal had been scratching there, so he looked inside, and there was another skunk, rolling, tossing and throwing his dead friend around. The next day when Mr. Fehrenbach returned to the spot there was "no sight or sound of either animal dead or alive. Has anyone, he asks, ever come across a similar occurrence?" ... An account of banding done by George $\mathrm{H}$. Lang at Indian Head covers a total of 6,208 birds between 1923 and 1939, including 1,662 Robins, 859 Blackcrowned Night Herons and 85 Burrowing Owls .... Early dates for bats were supplied by J. D. Ritchie of Wallwort: May 14, 1931: May 10, 1932, and May 7, 1934.

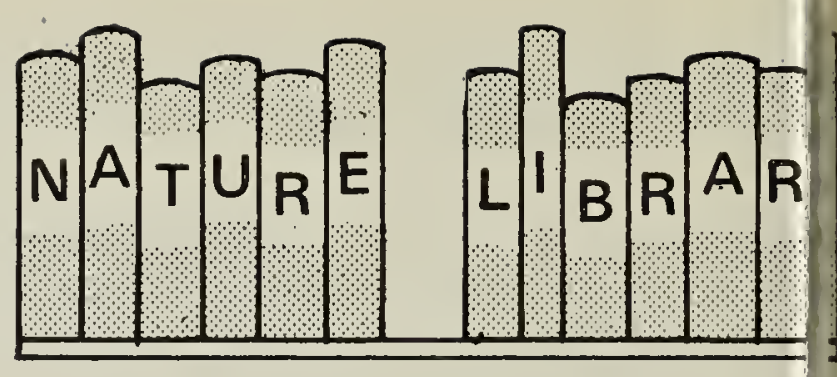

\section{SILTON SEASONS}

From the Diary of a Countryman

By. R. D. Symons

Published by Doubleday Canada Ltd. 105 Bond Street,

Toronto, Ontario, M5B 1 Y3

200 pp. January 1975. $\$ 7.95$

No, Mr. Symons, neither your sf it nor your pen has faltered in wort ly presenting your observations of a fe spent with joy and beauty. (Answe 0 last paragraph of Preface.)

Many millions of persons have $n$ re knowledge, scientific or otheru e. than R. D. Symons, but few mol Is have the gift of wisdom he possess

"Silton Seasons" consists of a tw ve month excerpt from Symons' di y, written after retirement from an $n$ teresting but hard, rugged life. He carries us through a year, montl jy month - each chapter a joy to any ne interested in nature whether bils, mammals, plants, trees or the wo er of clean air and glorious sk s. Symons' descriptive writing is su rb in its simplicity, and his obvious ve and knowledge of all things wild ad natural will continue to thrill ny nature lover, at the same time cre: ng awareness in those whose thou its have not yet awakened to the joy nd beauty surrounding us.

However, "Silton Seasons" is I re than a nature book. Each chi er displays a wealth of prairie histor ic tually experienced by the aut or Nostalgia for the old days is ter present yet he is sufficiently wi: to realize that time cannot stand sti machinery displaces the hose populations grow, methods of $t$ vel have changed the whole wold Although all these things have 1 a great extent contributed to spoilin the land he loved, he seldom shows b er- 